University of Nebraska - Lincoln

DigitalCommons@University of Nebraska - Lincoln

$11-1-2018$

\title{
Mortality and Flowering of Great Basin Perennial Forbs After Experimental Burning: Implications for Wild Bees
}

Byron G. Love

(USDA)-Agricultural Research Service Pollinating Insect Research Unit, byron.love@ars.usda.gov James H. Cane

(USDA)-Agricultural Research Service Pollinating Insect Research Unit

Follow this and additional works at: https://digitalcommons.unl.edu/usdaarsfacpub

Love, Byron G. and Cane, James H., "Mortality and Flowering of Great Basin Perennial Forbs After Experimental Burning: Implications for Wild Bees" (2018). Publications from USDA-ARS / UNL Faculty. 2155.

https://digitalcommons.unl.edu/usdaarsfacpub/2155

This Article is brought to you for free and open access by the U.S. Department of Agriculture: Agricultural Research Service, Lincoln, Nebraska at DigitalCommons@University of Nebraska - Lincoln. It has been accepted for inclusion in Publications from USDA-ARS / UNL Faculty by an authorized administrator of DigitalCommons@University of Nebraska - Lincoln. 


\title{
Mortality and Flowering of Great Basin Perennial Forbs After Experimental Burning: Implications for Wild Bees is
}

\author{
Byron G. Love ${ }^{\mathrm{a}, *}$, James H. Cane ${ }^{\mathrm{b}}$ \\ a Biological Science Technician, US Department of Agriculture (USDA) - Agricultural Research Service Pollinating Insect Research Unit, Logan, UT 84341, USA \\ ${ }^{\mathrm{b}}$ Research Entomologist, US Department of Agriculture (USDA) - Agricultural Research Service Pollinating Insect Research Unit, Logan, UT 84341, USA
}

\section{A R T I C L E I N F O}

\section{Article history:}

Received 2 February 2018

Received in revised form 30 October 2018

Accepted 1 November 2018

\section{Key Words:}

oligolecty

pollinators

restoration

sagebrush steppe

wildfire

wildflowers

\begin{abstract}
A B S T R A C T
The fates of native bee communities in the Great Basin sagebrush steppe are linked with the susceptibilities of their floral hosts to increasingly frequent wildfires. Postfire survival and subsequent flowering of six prevalent perennial wildflowers representing five families were quantified across a range of realistic fire severities created using a calibrated propane burn barrel. Five burn prescriptions of varying intensity and duration were applied to cultivated rows of basalt milkvetch (Astragalus filipes Torr. ex A. Gray), Blue Mountain prairie clover (Dalea ornata Eaton \& J. Wright), sulphur-flower buckwheat (Eriogonum umbellatum Torr.), fernleaf biscuitroot (Lomatium dissectum Nutt.), blue penstemon (Penstemon cyaneus Pennell), and gooseberryleaf globemallow (Sphaeralcea grossularifolia Hook. \& Arn.). Overall differences in their fire sensitivities were maximal at peak fire severity, ranging from $80 \%$ survival ( $L$. dissectum) to complete mortality (E. umbellatum and P. cyaneus). Although A. filipes survived well (85\%), half of the 95 burn survivors then failed to flower the year after burning. The postfire fate of plant-pollinator interactions is a function of the bees' nesting habits, their floral host's sensitivity to a given burn intensity (both in terms of survival and flowering), and the reproductive interdependence of bee and floral host (taxonomic specialists vs. generalists).
\end{abstract}

(c) 2018 The Society for Range Management. Published by Elsevier Inc. All rights reserved.

\section{Introduction}

Great Basin sagebrush steppe is among the most imperiled large terrestrial ecosystems in the United States (Noss et al., 1995; Stein et al., 2000; Davies et al., 2011; Miller et al., 2011). Once covering over 60 million ha in western North America (West, 2000; Beck et al., 2009), sagebrush-dominated communities have been substantially diminished; much that remains is fragmented and degraded (Walker and Shaw, 2005; Chambers et al., 2009; Chambers and Wisdom, 2009; Hanna and Fulgham, 2015). Their fire regimes have changed dramatically, owing to an accelerated fire cycle fueled by the invasion of aggressive and highly flammable annual Eurasion grasses, primarily cheatgrass (Bromus. tectorum L.) and medusahead (Taeniatherum caput-medusae [L.] Nevski) (D'Antonio and Vitousek, 1992; Brooks and Pyke, 2001; Chambers et al., 2007). Wildfires return not only more frequentlywith return intervals measured in years rather than decades

\footnotetext{
it Research was largely funded by the USDA Forest Service, Rocky Mountain Research Station, Great Basin Native Plant Selection and Increase Project, and the US Dept of the Interior Bureau of Land Management, Great Basin Restoration Initiative.

* Correspondence: Byron G. Love, USDA Pollinating Insect Research Unit, 1410 N 800 E Logan, UT 84341, USA.

E-mail address: byron.love@ars.usda.gov (B.G. Love).
}

(Whisenant, 1990)-but are also larger in size and more severe (Chambers and Pellant, 2008; Keane et al., 2008), sometimes removing all aboveground vegetation over tens of thousands of hectares (e.g., Love and Cane, 2016).

The sagebrush ecosystem in the US Intermountain West still hosts a diverse, albeit poorly known, bee fauna that relies on and also pollinates many of the native perennial wildflowers common to this region (Cane, 2008; Cane et al., 2012). Most bees of this and other temperate-zone regions excavate nests deep enough in soil that their progeny should escape lethal soil heating by rangeland fire to emerge as adults the next year (Cane and Neff, 2011). Our work in the Great Basin sagebrush steppe (Love and Cane, 2016; Love and Cane, unpublished) corroborates this prediction, finding diverse bee communities active in the weeks and years following a wildfire. To retain this persistent bee fauna, their floral hosts must not only survive fire but also produce timely and sufficient bloom the next growing season. Most bees have an annual lifecycle, similar to annual plants, but without the insurance of a seedbank to endure unfavorable periods (such as after a fire). Disrupted or diminished pollen and nectar supplies during the first growing season after a fire would constrain reproduction by the local surviving bee community, thereby limiting pollination during their recovery years.

Much is known about the general effects of fire on Great Basin plant communities and ensuing vegetation changes (e.g., West and Yorks, 
2002; Svejcar et al., 2017). However, many studies are not interpretable in ways relevant to wildflowers and the native bees that pollinate them, primarily because bees do not use the two dominant plant types in sagebrush steppe, namely wind-pollinated grasses and sagebrush (Artemsia L.) (West, 1988). Fire studies that do include bee-friendly plants (annual and perennial forbs) can reveal some postfire attributes relevant to bees, depending on taxonomic resolution. Unfortunately, most rangeland fire ecologists pool plant species as a single category, "forb" (e.g., Beck et al., 2009), or at best, merely sort them into perennial and annual forms (e.g., Rhodes et al., 2010; Bates et al., 2017) in order to quantify changes in their cover, abundance, or biomass production after fire. Such studies cannot differentiate winners from losers among individual forb species after fire, which is key information because different wildflower species host different combinations of wild bee species (guilds) (Cane and Love, 2016). Burned communities of both annual and perennial forbs come to resemble neighboring unburned habitat within a few years (West and Hassan, 1985; Seefeldt et al., 2007; Beck et al., 2009) and, depending on the site potential (Bates et al., 2017), can increase in cover or biomass for many years before decreasing as sagebrush stands mature (Blaisdell, 1953; Harniss and Murray, 1973). Because local bee diversity broadly correlates with floral diversity, bee communities should generally reflect this multiyear dynamic.

Bees have idiosyncratic resource requirements and a broad range of natural histories; however, that precludes the use of such coarse measures as cover and biomass production for meaningful understanding and prediction of how individual bee species respond to the indirect effects of fire (i.e., changes in host bloom availability). This is especially true for the many bee species that specialize on a few related floral hosts for their pollen needs (oligolecty) (Cripps and Rust, 1989; Small et al., 1997; Cane and Sipes, 2006), although even floral generalists have pronounced floral host preferences (Cane and Love, 2016). Moreover, bee species can also differ in the season and duration of adult foraging and nesting activity. Consequently, the species composition of the local bee community and their flowers both change throughout the growing season. Fire-induced changes in plant communities can therefore have different effects on different bees-neutral or favorable for some, negative for others-hence the need for understanding each wildflower's species-specific survival and flowering responses to fire.

Those few studies that do include blooming responses of specific herbaceous perennial forbs to fire offer more insights into the consequences of fire for specific bees (e.g., Platt et al., 1988; Wrobleski and Kauffman, 2003; Pavlovic et al., 2011). With few exceptions (e.g., West and Hassan, 1985; West and Yorks, 2002), the unpredictability of ignition and spread of wildfire precludes its use to compare plant communities before and after burning. For those comparisons, investigators turn to prescribed burns, which allow greater safety and temporal and spatial control. However, these fires typically burn less intensely and during different seasons (fall or spring) than the wildfires to which their results are often extrapolated (refer to DeBano et al., 1998). Nonetheless, studies using natural fire are limited to characterizing broadscale responses (population or community) because salient wildfire attributes such as flame height, rate of spread, residence time, and fireline intensity all vary in unknowable ways across the landscape (Sapsis and Kauffman, 1991; DeBano et al., 1998). Multiple factors contribute to fire intensity, including fuel load, moisture levels, aspect, slope, temperature, humidity, and wind speed. The result is a spatial mosaic of fire severities. Before wildfire, the presence, abundance, and distribution of each forb species is unknown, so fire-induced changes cannot be quantified. One solution to this dilemma is to track the fates of groups of individual plants after they are subjected to burning across a range of controlled, verifiable fire intensities.

This study uses a novel approach to test and compare the survival (resistance) and fitness (i.e., bloom) (resilience) responses of a select group of six prevalent Great Basin perennial forbs to increasing intensities of simulated wildfire. By integrating three existing methodologies, we are better able to understand the effects of fire on different forb species and, indirectly, the fates of resident bee species dependent on those forbs in the year after fire. In addition, our methodology allows for more confident attribution of the plants' responses to just fire intensity. First, we focus on the response of a single plant demographicnamely, reproductively mature plants. This differs from studies reporting fire-induced changes in abundance, which do not account for recruitment (in the case of increases) or differential mortality by age classes, such as more young plants succumbing to heating than older plants (Bond and Van Wilgen, 1996). Second, we used plants in cultivation, standardizing many confounding variables relevant to plant survival and performance that would be impossible to control for in natural experiments, including soil properties, nutrient and water availability, and pest and weed pressure. Third, we standardized the uniform application of increasing fire intensity (i.e., heat and duration) to provide repeatable replicated treatments for individuals of each plant species that represent the broad range of fire intensities expected within and between individual fires in sagebrush ecosystems, including both prescribed burns and wildfires.

\section{Methods}

\section{Study Area}

Cultivated, even-aged rows of reproductively mature wildflowers were studied at the 47-ha Oregon State University Malheur Experiment Station, located in eastern Oregon (Shock et al., 2012). The soil in this low-lying semiarid region is Nyssa silt loam (Lovell, 1980). The plants used were part of a larger study to develop cultivation practices (e.g., irrigation and seed harvesting methods) for many wild forb species common in sagebrush ecosystems of the Intermountain West (Shock et al., 2012). Cultivation practices standardized favorable conditions for plant growth, health, and vigor, factors that may otherwise vary widely and obscure the effects of fire (e.g., soil conditions, water, pest and weed pressure) (DeBano et al., 1979; Miller et al., 2013). All plants received four $5-\mathrm{cm}$ doses of subirrigated water during the growing season that supplemented local rainfall.

\section{Experimental Design}

We chose 6 of the 17 available herbaceous perennial forb species representing a range in taxonomy ( 5 families), morphologic characteristics, season of bloom, and importance to bees and other wildlife (Table 1). A randomized block design with four replicates was used to evaluate the survival and reproductive responses of burned plants to five incrementing intensities of simulated wildfire per species, plus an unburned control. Burn trials took place at the end of the natural fire season (Knapp et al., 2009) over a 10-d period, from 21 to 30 August, 2012. Combustion took place during daylight hours under mostly sunny conditions, with air temperatures ranging between $18^{\circ} \mathrm{C}$ and $36^{\circ} \mathrm{C}$. The plants tested were well into autumnal senescence (e.g., aboveground tissues had all-or mostly-died back). Before treatment application, $1-\mathrm{m}^{2}$ plots were demarked and live mature plants counted (see Table 1). Plants were trimmed to $10 \mathrm{~cm}$ in height, and loose dead vegetation was cleared from around the burn area for safety and to standardize minimal fuel loads.

\section{Heat Treatment}

A number of techniques have been used to simulate natural or prescribed fire. The better ones control time-temperature exposures to allow for relatively consistent, repeatable, and contained treatments. Most use portable metal fire enclosures to safely contain the fire fueled either by straw (Korfmacher et al., 2003), shredded paper (Wright and Klemmedson, 1965), or propane (Wright et al., 1976; Britton and Wright, 1979). Variations include fire rings (horizontal fuel jets) (Robberecht and Defosse, 1995) or hand-held propane torches (e.g., 
Table 1

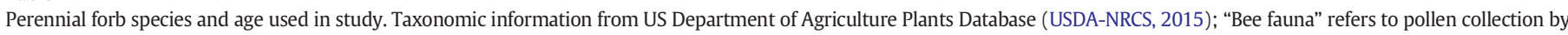

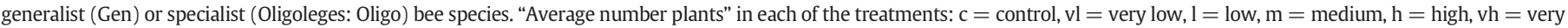
high intensity burn.

\begin{tabular}{|c|c|c|c|c|c|}
\hline $\begin{array}{l}\text { Species common name } \\
\text { (code) }\end{array}$ & Family & Bee fauna & Dormant appearance & Average number plants (std dev) & Yr planted \\
\hline $\begin{array}{l}\text { Astragalus filipes } \\
\text { Basalt milkvetch } \\
\text { (ASFI) }\end{array}$ & Fabaceae & Gen & Stout taproot, shallowly buried rootcrown & $\begin{array}{l}\mathrm{c}=4.3(1.0) \\
\mathrm{vl}=4.3(1.9) \\
\mathrm{l}=4.3(1.3) \\
\mathrm{m}=3.5(1.7) \\
\mathrm{h}=5.3(1.5) \\
\mathrm{vh}=6.5(1.9)\end{array}$ & 2009 \\
\hline $\begin{array}{l}\text { Dalea ornata } \\
\text { Blue Mountain prairie clover } \\
\text { (DAOR) }\end{array}$ & Fabaceae & Gen & Stout taproot, shallowly buried caudex & $\begin{array}{l}\mathrm{c}=5.0(2.2) \\
\mathrm{vl}=10.5(1.7) \\
\mathrm{l}=8.8(2.8) \\
\mathrm{m}=9.0(1.8) \\
\mathrm{h}=9.0(1.8) \\
\mathrm{vh}=6.8(2.6)\end{array}$ & 2009 \\
\hline $\begin{array}{l}\text { Eriogonum umbellatum } \\
\text { Sulphur-flower buckwheat } \\
\text { (ERUM) }\end{array}$ & Polygonaceae & Gen & Spreading woody caudex, dormant buds above surface & $\begin{array}{l}\mathrm{c}=6.8(2.2) \\
\mathrm{vl}=6.8(1.3) \\
\mathrm{l}=8.0(3.5) \\
\mathrm{m}=8.5(3.3) \\
\mathrm{h}=8.0(2.9) \\
\mathrm{vh}=9.0(3.4)\end{array}$ & 2005 \\
\hline $\begin{array}{l}\text { Lomatium dissectum } \\
\text { Fernleaf biscuitroot } \\
\text { (LODI) }\end{array}$ & Apiaceae & $\begin{array}{l}\text { Gen/ } \\
\text { Oligo }\end{array}$ & Massive taproot, buried rootcrown & $\begin{array}{l}\mathrm{c}=6.0(2.6) \\
\mathrm{vl}=5.0(2.8) \\
\mathrm{l}=4.0(1.2) \\
\mathrm{m}=6.5(3.0) \\
\mathrm{h}=4.5(1.9) \\
\mathrm{vh}=5.3(1.5)\end{array}$ & 2005 \\
\hline $\begin{array}{l}\text { Penstemon cyaneus } \\
\text { Blue penstemon } \\
\text { (PECY) }\end{array}$ & Scrophulariaceae & $\begin{array}{l}\text { Gen/ } \\
\text { Oligo }^{1}\end{array}$ & Thick taproot, branched caudex, buds at surface & $\begin{array}{l}\mathrm{c}=3.5(1.0) \\
\mathrm{vl}=3.5(1.3) \\
\mathrm{l}=3.3(1.5) \\
\mathrm{m}=3.0(0.8) \\
\mathrm{h}=4.8(2.2) \\
\mathrm{vh}=3.0(0.8)\end{array}$ & 2009 \\
\hline $\begin{array}{l}\text { Sphaeralcea grossulariifolia } \\
\text { Gooseberryleaf globemallow } \\
\text { (SPGR) }\end{array}$ & Malvaceae & $\begin{array}{l}\text { Gen/ } \\
\text { Oligo }\end{array}$ & Thick taproot, short-branched caudex & $\begin{array}{l}\mathrm{c}=6.5(1.0) \\
\mathrm{vl}=6.8(1.5) \\
\mathrm{l}=9.3(1.5) \\
\mathrm{m}=10.0(2.5) \\
\mathrm{h}=9.8(6.1) \\
\mathrm{vh}=10.3(3.7)\end{array}$ & 2006 \\
\hline
\end{tabular}

\footnotetext{
${ }^{1}$ Penstemon pollen is collected by pollen wasps in the genus Pseudomasaris.
}

Canadell and Lòpez-Soria, 1991). These methods offer experimental control and flexibility over spatial, temporal, and environmental factors associated with fire studies.

We chose to use the portable propane burner method using Wright et al. (1976) as a guide. A ring of mild steel sheeting $1 \mathrm{~m}$ tall $\times 1 \mathrm{~m}$ diameter contained 5 equally spaced internal gas jets model (Red Dragon 5-cm diameter 100000 BTU medium duty vapor torches, Flame Engineering Inc. LaCrosse, KS) positioned $20-25 \mathrm{~cm}$ above the soil surface. Gas jets were aligned to provide a linear strip ( $\approx 25 \mathrm{~cm}$ wide) of demonstrably consistent heating. Propane was delivered via an 18 -kg tank regulated by monitoring a 200-kPa (30-psi) pressure gauge (Pearson BG-2530). We developed a series of five incremental heating prescriptions (hereafter referred to as treatments) of increasing heating intensities (Table 2, Fig. 1). Together these represent the broad range of heating intensities experienced at the soil surface and $2 \mathrm{~cm}$ below the soil surface during "natural" and prescribed fires in sagebrush shrublands (reviewed in Miller et al., 2013).
Temperature data were collected using type K thermocouple probes (Omega TJ36-CAXL) recorded at 2-sec intervals (Omega RDXL4SD). Two pairs of thermocouples were placed in the direct path of the burner jets (left and right of center). A larger thermocouple (6.35 $\mathrm{mm}$ diameter) was pressed into the soil surface, leaving only the upper portion of the thermocouple tip exposed to direct contact with the flame. We found that this placement reduced otherwise extreme temperature fluctuations recorded when the thermocouple was simply laid on top of the soil (due presumably to slight ever-present variations in surface microrelief, which altered the amount of thermocouple surface area exposed to the flame). The second, smaller thermocouple (3.18 mm diameter) was buried $2 \mathrm{~cm}$ below the soil surface directly under the larger thermocouple. Figure S1 (available online at https://doi.org/10.1016/j. rama.2018.11.001) illustrates the variation in measured soil temperature exhibited during the heating trials for Medium and Very High intensity burn treatments. After each combustion period, the plots were sprayed with a liter of water to safely extinguish any embers during

Table 2

Fuel prescriptions and treatment codes for heating treatments and associated average peak temperatures $\left({ }^{\circ} \mathrm{C}\right)$ at the soil surface and $2 \mathrm{~cm}$ below soil surface.

\begin{tabular}{|c|c|c|c|c|}
\hline Treatment (code) & Prescription & Peak temp $\left({ }^{\circ} \mathrm{C}\right)$ at surface & Peak temp $\left({ }^{\circ} \mathrm{C}\right) 2 \mathrm{~cm}$ below surface & No. of trials \\
\hline Control (C) & No fuel applied & Ambient & Ambient & na \\
\hline Very Low (VL) & $52 \mathrm{kPa}(7.5 \mathrm{psi}), 25 \mathrm{sec}$ & $132 \pm 37$ & $49 \pm 4$ & 5 \\
\hline Low $(\mathrm{L})$ & $52 \mathrm{kPa}(7.5 \mathrm{psi}), 50 \mathrm{sec}$ & $241 \pm 60$ & $57 \pm 4$ & 15 \\
\hline Medium (M) & $103 \mathrm{kPa}(15 \mathrm{psi}), 65 \mathrm{sec}$ & $353 \pm 31$ & $66 \pm 6$ & 5 \\
\hline $\operatorname{High}(\mathrm{H})$ & $103 \mathrm{kPa}(15 \mathrm{psi}), 175 \mathrm{sec}$ & $500 \pm 78$ & $102 \pm 23$ & 8 \\
\hline Very High (VH) & $103 \mathrm{kPa}(15 \mathrm{psi}), 240 \mathrm{sec}$ & $629 \pm 52$ & $129 \pm 15$ & 5 \\
\hline
\end{tabular}




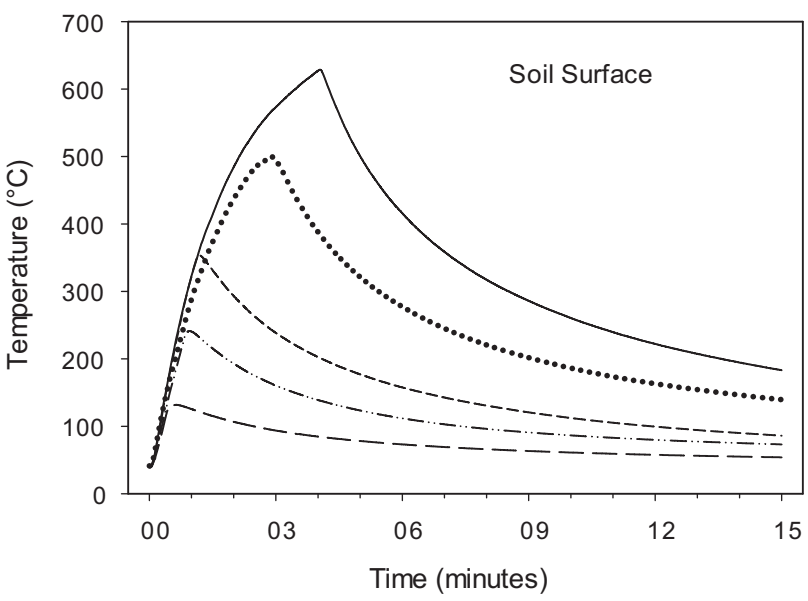

a)

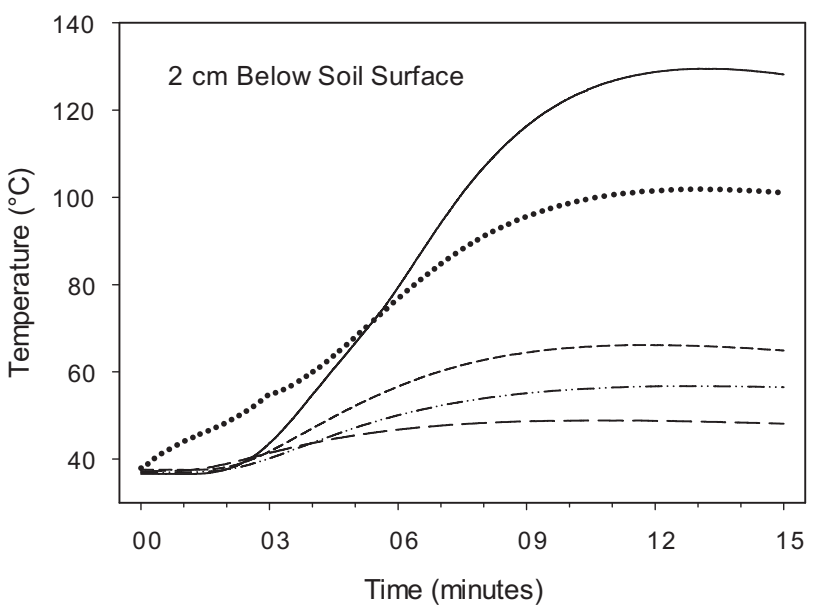

b)

$$
\begin{array}{|ll|}
\hline-\ldots . & \text { Very High } \\
\text {-..- } & \text { High } \\
-\cdots- & \text { Medium } \\
- & \text { Low } \\
- & \text { Very Low } \\
\hline
\end{array}
$$

Figure 1. Heating profiles $\left({ }^{\circ} \mathrm{C}\right)$ using treatment prescriptions (propane pressure and duration) described in Table 2 at $\mathbf{a}$, soil surface and $\mathbf{b}, 2 \mathrm{~cm}$ below ground for five burn intensities.

this dry part of the season. Before moving the portable burner, posttreatment temperature monitoring continued for about 15 minutes, until subsurface temperatures had peaked.

\section{Analysis}

Plant data were collected the next growing season during April and May 2013, counting again live plants in the strip of uniform heating across each plot. The relationship between fire intensity and individual mortality was tested using logistic regression. For all significant models, treatment effects were compared against control groups with a Dunnett post hoc multiple comparison test. Survival data were transformed by adding one to all counts when the control group value was zero (no mortality). All analyses used R Core Team (R version 2.14.1, Vienna, Austria) (R-Team, 2012) and an alpha of 0.05.

The relationship between fire intensity and several flowering parameters relevant to bees were also tested, specifically whether fire intensity suppressed all bloom (plants survived but did not bloom) or changed flower abundance. Not all parameters could be measured for all species. Bloom suppression was evaluated for Astragalus filipes using logistic regression described earlier. All other bloom parameters were tested using analysis of variance and pairwise multiple comparisons with Bonferroni adjustment for significant models. Data were log transformed to meet normality assumptions. Differences in bloom abundance were tested on all species, with the exception of Sphaeralcea grossulariifolia, because its resprouting confounded counts of survivors. A. filipes bloom abundance was estimated by counting the number of seed pods per plant, a conservative measure of earlier flower abundance (Watrous and Cane, 2011). For the remaining plant species, average numbers of flowering spikes (Dalea ornata), racemes (Penstemon cyaneus), or umbels (Eriogonum umbellatum and L. dissectum) per trial were used to calculate averages per surviving plant. Before burning, treatment groups had similar numbers of spikes, racemes, or umbels $(P>0.3)$. For $D$. ornata, we found that the flower number was highly correlated with spike length $\left(n=35, r^{2}=0.9\right)$ over a range of spike lengths, allowing use of summed spike lengths per plant as a proxy for total production of its tiny crowded flowers (Pavlovic et al., 2011). Data are presented as the mean \pm one standard deviation unless otherwise stated.

\section{Results}

The six species in this study, represented by 915 individual plants (see Table 1), exhibited species-specific responses to increasing intensities of experimental burning treatments. Mortality results are addressed first for all species, and then individual reproductive responses are reported in separate subsections.

\section{Mortality}

Incremental increases of fire intensities differentially influenced overall mortality for all species tested in this study except $L$. dissectum (Table 3). The six species can be sorted out into two response groups - "fire-tolerant" and "fire-intolerant" (refer to Miller et al., 2015) (Fig. 2 ). The two most intense heating treatments killed $41-100 \%$ of individual plants of three of the six species (E. umbellatum, P. cyaneus, and $S$. grossulariifolia) (Dunnett $P<0.02$ ) (see Fig. 2a). Plants of the tolerant group-L. dissectum, A. filipes, and $D$. ornata-largely survived burning at even the most extreme fire intensities (prolonged burns with surface temperatures $\geq 300^{\circ} \mathrm{C}$ ), rarely exceeding $30 \%$ mortality (see Fig. 2 b). Conversely, even the mildest fire intensity treatment killed $>30 \%$ of $E$. umbellatum and P. cyaneus. Together with S. grossulariifolia, intense heating killed $60-100 \%$ of plants representing these three fire-intolerant species (see Fig. 2a).

\section{Reproductive Responses}

\section{Lomatium dissectum}

Of the 125 individual plants in this group, 23 control plants persisted through the year (96\%), as did 94 of the burned (treated) plants $(93 \%$ survival) and all plants flowered. Their average number of umbels per plant was unaffected by burn intensity $(F=1.1 ; P=0.42)$. Before

Table 3

Logistic regression results (influence of heating on mortality). See Table 1 for plant species names.

\begin{tabular}{|c|c|c|c|c|c|c|}
\hline \multicolumn{2}{|l|}{ Plant } & \multicolumn{2}{|c|}{ Deviance (d.f.) } & \multicolumn{2}{|c|}{ Fisher } & \multirow[b]{2}{*}{$P$ value } \\
\hline code & $Z$ value & Null & Residual & AIC & iterations & \\
\hline ASFI & 2.22 & $84(111)$ & 78 (110) & 82 & 5 & 0.026 \\
\hline DAOR & 2.95 & 90 (195) & 78 (194) & 82 & 6 & 0.003 \\
\hline ERUM & 7.26 & $252(187)$ & $153(186)$ & 157 & 5 & $3.88 \mathrm{e}-13$ \\
\hline LODI & -0.56 & 59 (124) & 59 (123) & 63 & 5 & 0.58 \\
\hline PECY & 4.71 & $116(83)$ & $84(82)$ & 88 & 4 & $2.43 e-06$ \\
\hline SPGR & 5.02 & $198(172)$ & $164(171)$ & 168 & 5 & $5.12 \mathrm{e}-07$ \\
\hline
\end{tabular}

AIC indicates Akaike information criteria. 


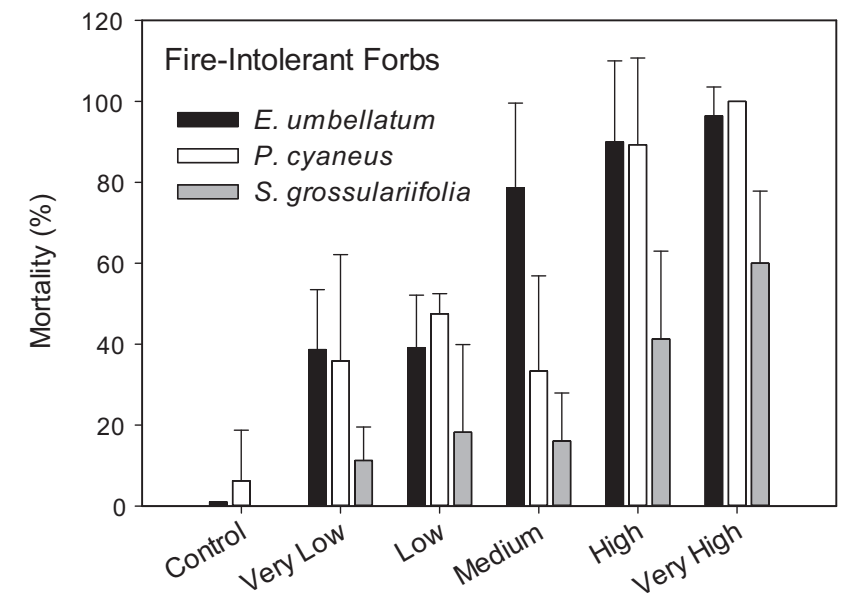

a)

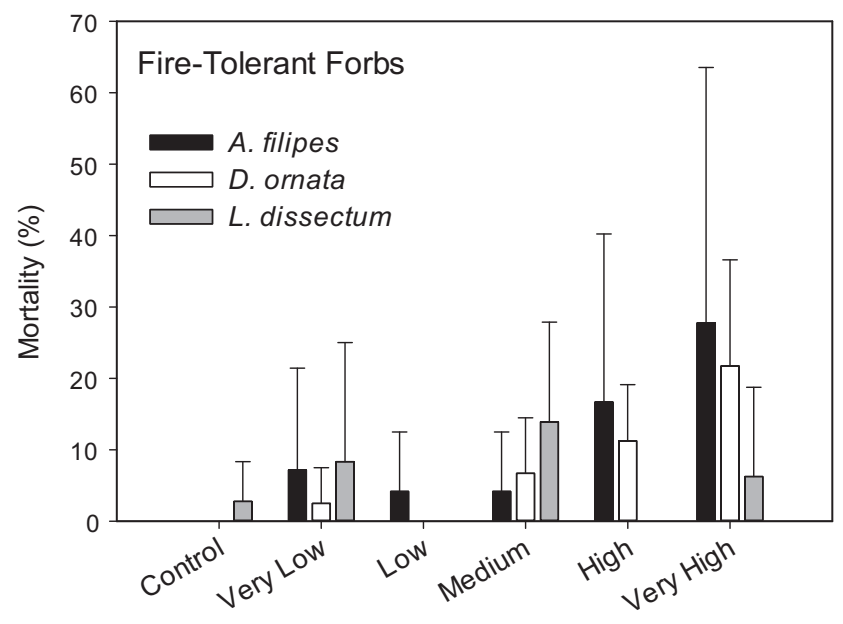

b)

Burn Intensity

Figure 2. Percentage mortality ( \pm std. dev.) of a, fire-intolerant and $\mathbf{b}$, fire-tolerant perennial forb species after burning. See Table 1 for plant species names.

burning, plants averaged two umbels each across all control and treatment plots. A year later, after burning, umbel counts doubled or tripled (ranging from 4 to 6 ).

\section{Astragalus filipes}

Of the 112 plants in this group, all 17 controls persisted through the year, as did 81 of the burned plants ( $85 \%$ survival). Burn intensity was a significant factor for predicting bloom among surviving $A$. filipes individuals the year after burning $(z=2.41, P=0.02)$. Half as many surviving plants bloomed after high-intensity burning compared with unburned controls (40\% vs. $87 \%$ ) (Dunnett test, $z=-2.55, P=0.04$ ) (Fig. 3). However, among openly pollinated survivors that did bloom, seed pod production was similar across fire intensities (average 46-272 pods per plant $)(F=1.81, P=0.16)$.

\section{Dalea ornata}

Of the 196 plants in this group, all 20 control plants survived, as did 164 burned plants (93\% survival). All but one survivor flowered the following summer. Fire intensity did somewhat affect the cumulative number of flowering spikes per plant $(F=3.00, P=0.045)$, but no pair-wise comparisons were significant. Burned $D$. ornata produced 25-115 spikes per plant. The averaged sum of spike lengths produced

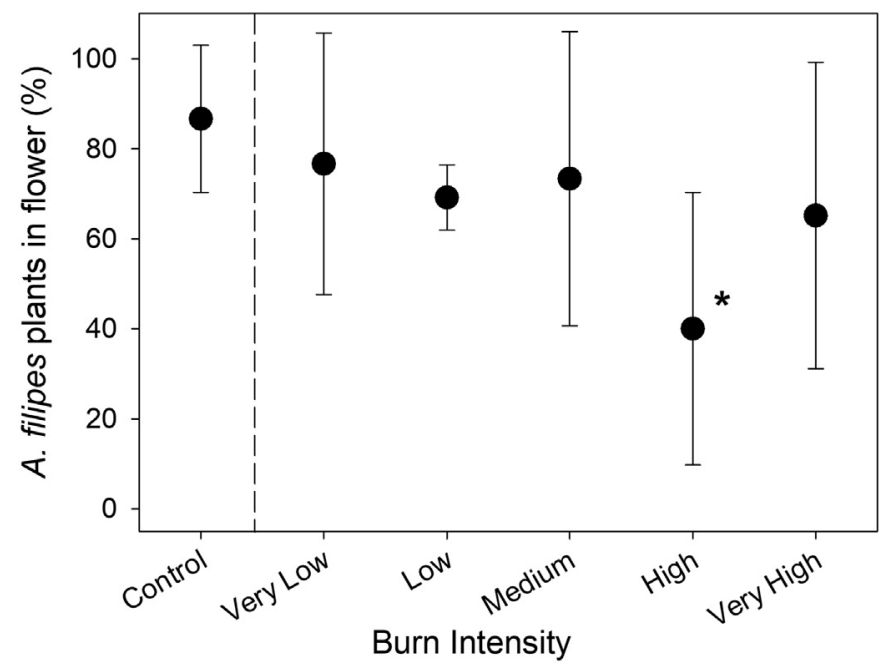

Figure 3. Fewer Astragalus filipes survivors flowered after High intensity burning; asterisk indicates significant difference compared with control using the Dunnett post hoc multiple comparison test ( \pm standard deviation).

per plant in each treatment (as a surrogate for flower counts) did not change with increasing fire intensity $(P=0.08)$.

\section{Penstemon cyaneus}

Of the 84 individual plants in this group, 13 control plants survived (93\%), whereas only 27 survived burning (39\%). The response of bloom-to-burn intensity was analyzed at the plot level because data had not been collected by individual plant. Instead, we counted the total numbers of flowering racemes per plot in each trial, from which we calculated an average number of racemes per plant. Consequently, we can only report a failure to bloom when the sum of racemes in a plot was zero. We are therefore confident that at a minimum, 11 of the 27 survivors (41\%) failed to flower. Of the 16 plants that did bloom, burning reduced the numbers of racemes in all treatments $(F$ $=4.99, P=0.005$ ) except for the mildest fire intensity (Very Low) (pairwise multiple comparison test with Bonferroni adjustment, $P=$ 0.053) (Fig. 4). In the year after burning, plants in the Control and Very Low fire treatment produced an average of 9-11 racemes each, which was about two racemes fewer than the year before. In contrast,

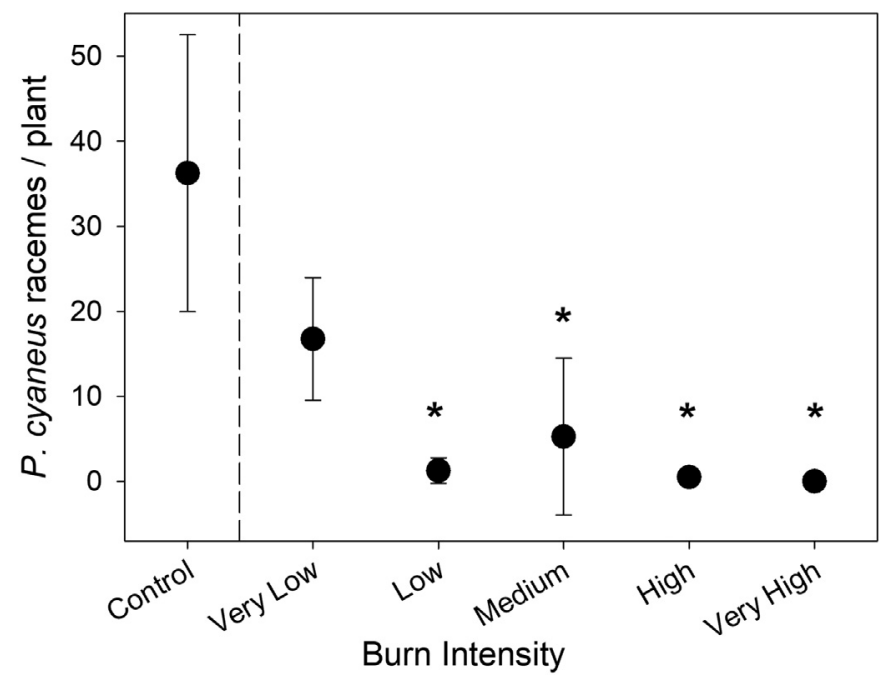

Figure 4. Burn intensity reduced racemes counts on $P$. cyaneus survivors except at the lowest (Very Low) intensity; asterisks indicate significant difference compared with control using pairwise multiple comparison test with Bonferroni adjustment ( \pm standard deviation). 
survivors of Low and Medium fire intensities averaged fewer than two racemes each and the three plants surviving the High intensity burning together produced only two racemes. No plants survived the Very High treatment.

\section{Eriogonum umbellatum}

Of the 188 individual plants in this group, all 27 control plants were alive the year after treatment, whereas only 48 survived burning (30\%). As with PECY, we could not test whether fire suppressed bloom but we can report that at least 22 survivors (46\%) failed to flower. Those that did bloom produced significantly fewer umbels than unburned controls $(F=18.02 ; P<0.0001)$ (Fig. 5), regardless of fire intensity $(P<0.0001)$. Umbel counts in the control group doubled in the year following burn treatments (from 12 to 28 per plant), whereas survivors of the three milder burn intensities (Very Low, Low, and Medium) produced far fewer umbels after burning (dropping from 10 to 2 per plant). The four plants surviving the hottest fire intensity (Very Hot) failed to flower.

\section{Discussion}

The reciprocal nature of the plant-pollinator relationship requires the continued and uninterrupted presence of both participants. Landscape-level disturbances like fire can temporarily disrupt this relationship by removing the supplies of pollen and nectar needed by bees and thereby the pollination services that they provide to wildflowers. The outcomes of such disruptions are of interest to land managers tasked with rehabilitation, especially in sagebrush ecosystems, where wildfires are growing in size, frequency, and intensity compared with historical norms (e.g., Chambers and Wisdom, 2009). The results of this study advance the work of others in the Great Basin, showing that fire intensity is a defining-albeit variable-factor influencing survival and reproduction of perennial herbaceous forbs.

The species studied here represent a spectrum of fire sensitivities, underscoring the key role of plant species identity for characterizing fire severity in a wildflower community. On the one hand, species like L. dissectum are virtually fireproof, surviving and flowering well across a range of fire intensities. Likewise, both $A$. filipes and $D$. ornata were resistant to a broad range of fire intensities, but some surviving plants then failed to bloom. At the other extreme, both P. cyaneus and $E$. umbellatum were vulnerable to even the mildest fire intensities, and those that did survive were less likely to bloom. Insights into the fates

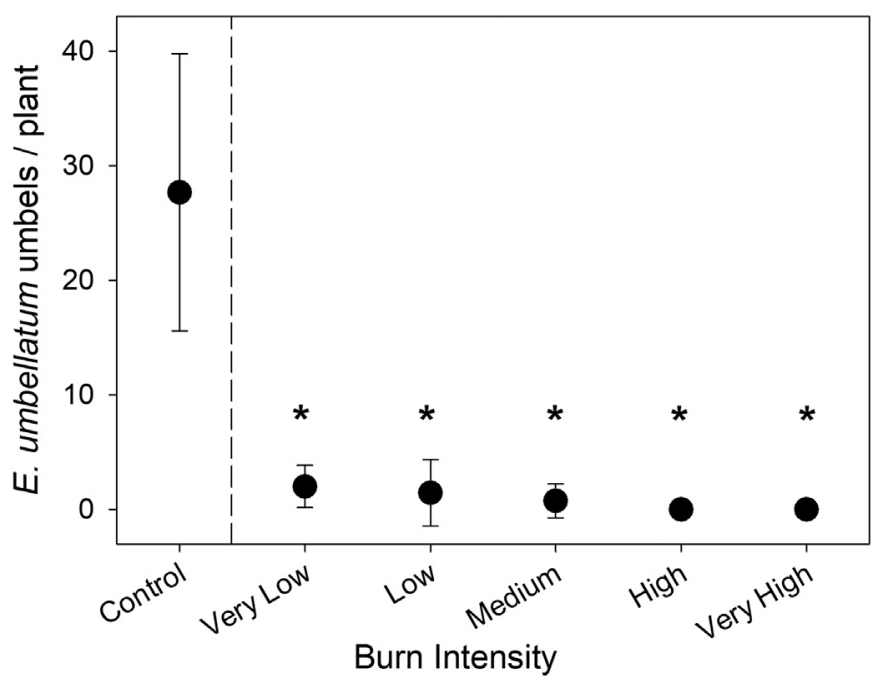

Figure 5. Burn intensity sharply reduced umbel counts on E. umbellatum survivors; asterisks indicate significant difference compared with control using pairwise multiple comparison test with Bonferroni adjustment ( \pm standard deviation). of local plant-pollinator relationships can be gained when comparing the species-specific survival and flowering probabilities of wildflowers with natural history traits of the bee species in their floral guilds-specifically nesting habits and breadth of diet. How these bee traits combine with wildflower fire susceptibility to predict the fate of their interaction can be illustrated by the following example combinations of wildflowers and their guilds of bees.

Resource specialization is a trait that can increase a species's risk of extinction (or local extirpation) (Groom et al., 2005). This type of risk is exemplified by the pollen wasp Pseudomasaris vespoides, a prevalent pollen specialist (oligolege) for some Great Basin Penstemon species (Torchio, 1974; Gess, 1996). Most wasps feed their young a diet of animal protein, but larval Pseudomasaris (Masarinae) wasps receive a pollen diet (Gess, 1996). Adult wasps construct mud nests against aboveground surfaces of rocks and woody stems. The Penstemon hosts of $P$. vespoides, including $P$. cyaneus, seem vulnerable to fire (inferred in Pechanec et al., 1944). We found that half of $P$. cyaneus plants burned in this study died after even mild heating, and high-intensity fire completely eradicated this species. In addition, at least $22 \%$ of the surviving plants failed to bloom the year after fire and those that did produced 40-60\% fewer flowering racemes. Burn mortality, coupled with curtailed bloom among survivors, will sharply diminish available Penstemon bloom the year after fire. Being an oligolege, $P$. vespoides cannot exploit other flowering genera. Moreover, the exposed nests of Pseudomasaris render them susceptible to lethal heating by fire as well. In this example, the plant and pollinator are both at risk of extirpation from the burned area. Presumably they will eventually recolonize, although the larger fires now common in the Great Basin (Chambers and Pellant, 2008; Keane et al., 2008), will slow recolonization (Love and Cane, 2016).

By itself, such taxonomic specialization is not a factor that always exacerbates vulnerability to fire. Other natural history traits-of both the pollinator and plant-must be considered. For instance, across the Great Basin, a group of small solitary bees (Andrena, esp. subgenus Micrandrena) (Ribble, 1968) seem to be consistently reliant on species of Lomatium for pollen to provision their nests (Cane and Love, 2016 and personal observation). Adults of these oligolectic Andrena bees are active only in the early spring, well before the fire season. Like all Andrena, their soil nests are excavated deeply enough that their progeny escape lethal temperatures (Cane and Neff, 2011). Thus, all life stages of these Lomatium pollinators are safe from fire. As others have earlier reported (Kaye et al., 2001; Miller et al., 2015; Wrobleski and Kauffman, 2003), we regularly found populations of Lomatium to be present in the years after fire (Cane and Love unpublished). Our experiments showed that these plants are likely survivors, as mature L. dissectum grew and bloomed the year after even after the most intense burning treatment. As with Micrandrena nests, we expect that Lomatium taproots benefit from the sharp attenuation of surface heating with soil depth (DeBano, 2000). We measured taproot crown depths in one population of mature L. dissectum growing naturally near Logan, Utah, finding them buried $6 \mathrm{~cm}$ beneath the soil surface $(n=20$, range $3.5-8 \mathrm{~cm})$, deep enough to realize a dramatic reduction in surface heating. For $L$. dissectum and Micrandrena, their mutually specialized plant-pollinator relationship is nearly fireproof, owing to the early spring bloom and robust fire protection of the buried taproot of Lomatium, coupled with the soil nesting habit and spring flight season of their oligolectic Micrandrena bees. If both are present before a fire, we can be confident they will be present after, regardless of fire intensity.

This stark contrast in postfire survival between $P$. cyaneus and $L$. dissectum likely results from the exact positions of basal buds relative to the soil surface and the proportions of plants thus exposed, rather than any innate differences in thermal tolerance. For our hottest burn treatment, a thermocouple tip buried just $2 \mathrm{~cm}$ below the soil surface was $500^{\circ} \mathrm{C}$ cooler than one placed at the soil surface (see Table 2). Given this insight for the thermal insulation of buried dormant buds, we can reasonably extend our results to some other groups of 
herbaceous perennial wildflowers that are common in sagebrush steppe. Species like $L$. dissectum (and its congenerics) that grow from a taproot or bulb often have their dormant basal buds well below the soil surface. In the Great Basin flora, these would include bulb-forming species in the Liliales (e.g., Allium, Camassia and Toxicoscordion) and many tap-rooted Asteraceae (e.g., Balsamorhiza and Crepis) and Fabaceae (e.g., Astragalus and Dalea). Like L. dissectum and A. filipes, we expect plants of these taxa to survive many Great Basin fires. Conversely, the woody twigs of $E$. umbellatum and surface rosettes of $P$. cyaneus bear the basal dormant bud(s) where they experience the direct surface heat of flames during fires. Most of the hundreds of other species of Eriogonum and Penstemon have similar dormant forms and so should also be vulnerable to wildfire. For other wildflower taxa, we were not satisfied with our ability to measure the precise placement of a plant's basal buds relative to the soil surface, particularly away from our controlled agricultural setting.

We encountered several serendipitous field opportunities the year after a wildfire to ground-truth these predictions of fire tolerance among Great Basin forbs. At several locations (near Hanford, Washington and King Hill, Idaho), we found large scattered plants of $D$. ornata persisting in dense stands of uninterrupted cheatgrass. Recent wildfires had facilitated cheatgrass's dominance at this site (Chambers et al., 2007). The persistence of mature blooming $D$. ornata plants after these fires is consistent with results from our experiments. In 2013, we surveyed wildflowers and bees the spring after a wildfire in northern Elko County, Nevada. Large mature sagebrush had been burned down to charred stumps. Despite the apparent severity of the fire and in accord with our experimental results, we found several hundred robust A. filipes plants blooming the year after burning. The bases of these plants were visibly charred (Fig. S2; available online at https://doi.org/ 10.1016/j.rama.2018.11.001) showing that the fire had burned over them without killing them or deterring bloom. Their numerous flowers were being visited by ground-nesting Eucera and Osmia bees. In contrast, the year after a wildfire west of Grouse Creek, Utah, we found that $A$. filipes beyond the fire perimeter was similarly robust and laden with bloom (and bees), but those inside the fire perimeter were far shorter and lacked bloom. This fire burned through juniper woodland and so may have been hotter. Each of these forb responses is consistent with the results of our burning experiments.

Fire-tolerant forbs can differ in their value to the broader Great Basin bee community. At one extreme, $L$. dissectum attracts a small guild of ground-nesting solitary bees, mostly Andrena, and in particular, two oligolectic Micrandrena (Cane and Love, 2016). These species are shared with other Lomatium (e.g., L. ambiguum, L. nudicaule, L. triternatum) but no other forbs that we have surveyed (Cane and Love, 2016). After fire, these bees will continue to faithfully pollinate various Lomatium, but little else. In contrast, $A$. filipes attracts a taxonomically rich guild of native bees, primarily solitary species of Anthidium, Eucera, and Osmia plus social bumble bees (Bombus) (Cane and Love, 2016). None appear to be oligolectic. Of the 85 bee species collected at A. filipes, 32 are Osmia, representing one-fourth of the entire named U.S. Osmia fauna (Cane and Love, 2016). We have collected A. filipes bees visiting both other Great Basin legumes (e.g., Dalea, Hedysarum, Lupinus, and other Astragalus) and genera of other families (e.g., Allium, Camassia, and Phacelia). After fire, surviving $A$. filipes can thus feed its diverse guild of bees that in turn visit and likely pollinate a diverse mix of other forbs in the Great Basin. Conversely, where A. filipes is reintroduced by seeding after fire, it is likely to have at least one of its necessary pollinators (Watrous and Cane, 2011) already available in all but the most degraded plant communities. Like A. filipes, species of Balsamorhiza also have diverse guilds of bees ( 76 species for $B$. sagitatta) that are shared with other flower genera (Cane and Love, 2016). Like L. dissectum, species of Balsamorhiza are likely rendered fireproof by their deep taproots and vernal flowering (Pechanec et al., 1944). By integrating knowledge of the common forbs in their local communities with insights into their likely fire susceptibilities and guilds of bees, local land managers can strategically choose forbs for reseeding mixes that best benefit desired native bees that will pollinate additional forbs and/or have readymade pollinators at hand after a wildfire.

\section{Implications}

The fates of native bees after fire in sagebrush habitats are inextricably linked with the fates of their native floral hosts and vice versa. Where fire eliminates fire-intolerant forbs, their surviving pollinators would suffer diminished reproduction, switch to fire-tolerant local hosts (unless oligolectic), or be forced to try dispersing beyond the burn perimeter. In turn, a vacated local bee fauna jeopardizes sexual reproduction of their recovering floral hosts in later years, particularly in the Great Basin, where the common perennial forbs typically benefit from, or require, pollinating bees (Cane, 2008). Identifying vulnerable plant-pollinator relationships is an important conservation goal, as in the case of the mutual fire intolerance of Penstemon and Pseudomasaris. However, as the Lomatium/Andrena relationship illustrates, other specialized plant-pollinator relationships endure fire. Rangeland managers wanting to leverage scarce restoration resources can take advantage of forbs that attract diverse generalist bees. Fostering fire-tolerant $A$. filipes and $D$. ornata, for instance, would support dozens of generalist bee species. These bees can use and pollinate many additional floral hosts in the flora of the sagebrush steppe.

Supplementary data to this article can be found online at https://doi. org/10.1016/j.rama.2018.11.001.

\section{Acknowledgments}

Liesl Cannon and Seth Naftziger assisted in data collection. Ellen Klinger and Chris McGlone assisted with design and analysis. Clint Shock of Oregon State University's College of Agricultural Sciences provided the plants and graciously offered field site housing. Nancy Shaw provided assistance in the experimental design and manuscript editing.

\section{References}

Bates, J.D., Davies, K.W., Hulet, A., Miller, R.F., Roundy, B., 2017. Sage grouse groceries: forb response to piñon-juniper treatments. Rangeland Ecology \& Management 70 106-115.

Beck, J.L., Connelly, J.W., Reese, K.P., 2009. Recovery of greater sage-grouse habitat features in Wyoming big sagebrush following prescribed fire. Restoration Ecology 17 393-403.

Blaisdell, J.P., 1953. Ecological effects of planned burning of sagebrush-grass range on the upper Snake River Plains. Technical Bulletin No. 1075. USDA Intermountain Forest and Range Experiment Station, Ogen, UT, USA 39 p.

Bond, W.J., Van Wilgen, B.W., 1996. Fire and plants. Volume 14 of population and community biology series. Chapman \& Hall, London, UK 263 p.

Britton, C.M., Wright, H.A., 1979. A portable burner for evaluating effects of fire on plants. Journal of Range Management 32, 475-476.

Brooks, M.L., Pyke, D.A., 2001. Invasive plants and fire in the deserts of North America. In: Galley, K.E.M., Wilson, T.P. (Eds.), Proceedings of the Invasive Species Workshop: the Role of Fire in the Control and Spread of Invasive Species. Fire Conference 2000: the First National Congress on Fire Ecology, Prevention, and Management. Miscellaneous Publication No. 11. Tall Timbers Research Station, Tallahassee, FL, USA, pp. 1-14.

Canadell, J., Lòpez-Soria, L., 1991. Resprouting vigour of two Mediterranean shrub species after experimental fire treatments. Vegetatio 95, 119-126.

Cane, J.H., 2008. Pollinating bees crucial to farming wildflower seed for US habitat restoration. In: James, R.R., Pitts-Singer, T.L. (Eds.), Bee pollination in agricultural ecosystems. Oxford University Press, New York, NY, USA, pp. 48-64.

Cane, J.H., Love, B., 2016. Floral guilds of bees in sagebrush steppe: comparing bee usage of wildflowers available for postfire restoration. Natural Areas Journal 36, 377-391.

Cane, J.H., Love, B., Swoboda, K., 2012. Breeding biology and bee guild of Douglas' Dustymaiden, Chaenactis Douglasii (Asteraceae, Helenieae). Western North American Naturalist 23, 563-568.

Cane, J.H., Neff, J.L., 2011. Predicted fates of ground-nesting bees in soil heated by wildfire: thermal tolerances of life stages and a survey of nesting depths. Biological Conservation 144, 2631-2636.

Cane, J.H., Sipes, S., 2006. Characterizing floral specialization by bees: analytical methods and a revised lexicon for oligolecty. In: Waser, N., Ollerton, J. (Eds.), Plant-pollinator interactions: from specialization to generalization. University of Chicago Press, Chicago, IL, USA, pp. 99-122

Chambers, J.C., Leger, E., Goergen, E., 2009. Cold desert fire and invasive species management: resources, strategies, tactics, and response. Rangelands 31, 14-20. 
Chambers, J.C., Pellant, M., 2008. Climate change impacts on northwestern and intermountain United States rangelands. Rangelands 30, 29-33.

Chambers, J.C., Roundy, B.A., Blank, R.R., Meyer, S.E., Whittaker, A., 2007. What makes Great Basin sagebrush ecosystems invasible by Bromus tectorum? Ecological Monographs 77, 117-145.

Chambers, J.C., Wisdom, M.J., 2009. Priority research and management issues for the imperiled Great Basin of the western United States. Restoration Ecology 17, 707-714.

Cripps, C., Rust, R.W., 1989. Pollen preferences of seven Osmia species (Hymenoptera: Megachilidae). Environmental Entomology 18, 133-138.

D’Antonio, C.M., Vitousek, P.M., 1992. Biological invasions by exotic grasses, the grass/fire cycle, and global change. Annual Review of Ecology and Systematics 23, 63-87.

Davies, K.W., Boyd, C.S., Beck, J.L., Bates, J.D., Svejcar, T.J., Gregg, M.A., 2011. Saving the sagebrush sea: an ecosystem conservation plan for big sagebrush plant communities. Biological Conservation 144, 2573-2584.

DeBano, L.F., 2000. The role of fire and soil heating on water repellency in wildland environments: a review. Journal of Hydrology 231-232, 195-206.

DeBano, L.F., Neary, D.G., Ffolliott, P.F., 1998. Fire's effects on ecosystems. John Wiley and Sons, New York, NY, USA 333 p.

DeBano, L.F., Rice, R.M., Conrad, C.E., 1979. Soil heating in chaparral fires: effects on soil properties, plant nutrients, erosion, and runoff. Research Paper PSW-RP-145. USDA Forest Service, Pacific Southwest Forest and Range Experiment Station, Berkeley, CA, USA $21 \mathrm{p}$.

Gess, S.K., 1996. The pollen wasps: ecology and natural history of the Masarinae. Harvard University Press, Cambridge, MA, USA 340 p.

Groom, M.J., Meffe, G.K., Carroll, C.R., 2005. Principles of conservation biology. 3rd ed. Sinauer Associates, Inc., Sumderland, MA, USA 779 p.

Hanna, S.K., Fulgham, K.O., 2015. Post-fire vegetation dynamics of a sagebrush steppe community change significantly over time. California Agriculture 69, 36-42.

Harniss, R.O., Murray, R.B., 1973. 30 years of vegetal change following burning of sagebrush-grass range. Journal of Range Management 26, 322-325.

Kaye, T.N., Pendergrass, K.L., Finley, K., Kauffman, J.B., 2001. The effect of fire on the population viability of an endangered prairie plant. Ecological Applications 11, $1366-1380$

Keane, R.E., Agee, J.K., Fulé, P., Keeley, J.E., Key, C., Kitchen, S.G., Miller, R., Schulte, L.A., 2008. Ecological effects of large fires on US landscapes: benefit or catastrophe? International Journal of Wildland Fire 17, 696-712.

Knapp, E.E., Estes, B.L., Skinner, C.N., 2009. Ecological effects of prescribed fire season: literature review and synthesis for managers. Albany, CA, USA: General Technical Report PSW-GTR-224. USDA Forest Service, Pacific Southwest Research Station 80 p.

Korfmacher, J.L., Chambers, J.C., Tausch, R.J., Roundy, B.A., Meyer, S.E., Kitchen, S., 2003. Technical note: a technique for conducting small-plot burn treatments. Journal of Range Management 56, 251-254.

Love, B.G., Cane, J.H., 2016. Limited direct effects of a massive wildfire on its sagebrush steppe bee community. Ecological Entomology 41, 317-326.

Lovell, B.B., 1980. Soil survey of Malheur County, Oregon, northeastern part. USDA Soi Conservation Service in cooperation with Oregon Agricultural Experiment Station, Corvallis, OR, USA $94 \mathrm{p}$.

Miller, R.F., Chambers, J.C., Pellant, M., 2015. A field guide for rapid assessment of postwildfire recovery potential in sagebrush and pinon-juniper ecosystems in the Great Basin. General Technical Report RMRS-GTR-338. USDA Forest Service, Rocky Mountain Research Station, Fort Collins, CO, USA 70 p.

Miller, R.F., Chambers, J.C., Pyke, D.A., Pierson, F.B., Williams, C.J., 2013. A review of fire effects on vegetation and soils in the Great Basin region: response and ecological site characteristics. General Technical Report RMRS-GTR-308. USDA Forest Service, Rocky Mountain Research Station, Fort Collins, CO, USA 126 p.

Miller, R.F., Knick, S.T., Pyke, D.A., Meinke, C.W., Hanser, S.E., Wisdom, M.J., Hild, A.L., 2011 Characteristics of sagebrush habitats and limitations to long-term conservation. In: Knick, S.T., Connelly, J.W. (Eds.), Greater sage-grouse: ecology and conservation of landscape species and its habitats. Studies in Avian Biology No. 38. University of California, Berkeley, CA, USA, pp. 145-184.

Noss, R.F., LaRoe, E.T., Scott, J.M., 1995. Endangered ecosystems of the United States: a preliminary assessment of loss and degradation. US Department of the Interior, National Biological Service, Washington, DC, USA 62 p.

Pavlovic, N.B., Leicht-Young, S.A., Grundel, R., 2011. Short-term effects of burn season on flowering phenology of savanna plants. Plant Ecology 212, 611-625.
Pechanec, J.F., Stewart, G., Blaisdell, J.P., 1944. Sagebrush burning: good and bad. Farmer's Bulletin No. 1948. US Department of Agriculture, Washington, DC, USA 34 p.

Platt, W.J., Evans, G.W., Davis, M.M., 1988. Effects of fire season on flowering of forbs and shrubs in longleaf pine forests. Oecologia 76, 353-363.

R Core Team, 2012. R: a language and environment for statistical computing. R Foundation for Statistical Computing, Vienna, Austria Available at. http://www.R-project. org/, Accessed date: 12 December 2015.

Rhodes, E.C., Bates, J.D., Sharp, R.N., Davies, K.W., 2010. Fire effects on cover and dietary resources of sage-grouse habitat. Journal of Wildlife Management 74, 755-764.

Ribble, D.W., 1968. Revisions of two subgenera of Andrena: Micrandrena Ashmead and Derandrena, new subgenus (Hymenoptera: Apoidea). Bulletin of the University of Nebraska State Museum 8, 237-294.

Robberecht, R., Defosse, G.E., 1995. The relative sensitivity of two bunchgrass species to fire. International Journal of Wildland Fire 5, 127-134

Sapsis, D.B., Kauffman, J.B., 1991. Fuel consumption and fire behavior associated with prescribed fires in sagebrush ecosystems. Northwest Science 65, 173-179.

Seefeldt, S.S., Germino, M., DiCristina, K., 2007. Prescribed fires in Artemisia tridentata ssp. vaseyana steppe have minor and transient effects on vegetation cover and composition. Applied Vegetation Science 10, 249-256.

Shock, M.P., Shock, C.C., Feibert, E.B.G., Shaw, N.L., Saunders, L.D., Sampangi, R.K., 2012. Cultivation and irrigation of fernleaf biscuitroot (Lomatium dissectum). Horticultural Science 47, 1525-1528.

Small, E., Brookes, B., Lefkovitch, L.P., Fairey, D.T., 1997. A preliminary analysis of the floral preferences of the alfalfa leafcutting bee, Megachile rotundata. Canadian Field-Naturalist $111,445-453$.

Stein, B.A., Kutner, L.S., Adams, J.S., 2000. Precious heritage: the status of biodiversity in the United States. Oxford University Press, New York, NY, USA 426 p.

Svejcar, T., Boyd, C., Davies, K., Hamerlynck, E., Svejcar, L., 2017. Challenges and limitations to native species restoration in the Great Basin, USA. Plant Ecology 218, 81-94.

Torchio, P.F., 1974. Mechanisms involved in the pollination of Penstemon visited by the Masarid wasp, Pseudomasaris vespoides (Cresson) (Hymenoptera: Vespoidea). The Pan-Pacific Entomologist 50, 226-234.

USDA-NRCS, 2015. The PLANTS Database. Available at:. http://plants.usda.gov, Accessed date: 12 December 2015.

Walker, S.C., Shaw, N.L., 2005. Current and potential use of broadleaf herbs for reestablishing native communities. In: Shaw, N.L., Pellant, M., Monsen, S.B. (Eds.), Sage-Grouse Habitat Restoration Symposium Proceedings RMRS-P-38. USDA, Forest Service, Rocky Mountain Research Station, Boise, ID, USA, pp. 56-61.

Watrous, K.M., Cane, J.H., 2011. Breeding biology of the threadstalk milkvetch, Astragalus filipes (Fabaceae), with a review of the genus. American Midland Naturalist 165, 225-240.

West, N.E., 1988. Intermountain deserts, shrub steppes, and woodlands. In: Barbour, M.G., Billings, W.D. (Eds.), North American terrestrial vegetation. Cambridge University Press, New York, NY, USA, pp. 209-230.

West, N.E., 2000. Synecology and disturbance regimes of sagebrush steppe ecosystems. In: Entwistle, P.G., DeBolt, A.M., Kaltenecker, J.H., Steenhof, K. (Eds.), Proceedings: Sagebrush Steppe Ecosystems Symposium. US Department of the Interior, Bureau of Land Management, Boise, ID, USA, pp. 15-26.

West, N.E., Hassan, M.A., 1985. Recovery of sagebrush-grass vegetation following wildfire. Journal of Range Management 38, 131-134

West, N.E., Yorks, T.P., 2002. Vegetation responses following wildfire on grazed and ungrazed sagebrush semi-desert. Journal of Range Management 55, 171-181.

Whisenant, S.G., 1990. Changing fire frequencies on Idaho's Snake River Plains: ecological and management implications. In: McArthur, E.D., Romney, E.M., Smith, S.D., Tueller, P.T. (Eds.), General Technical Report, INT-GTR-276: Proceedings Symposium on Cheatgrass Invasion, Shrub Die-Off, and Other Aspects of Shrub Biology and Management. USDA Forest Service, Intermountain Research Station, Ogden, UT, USA, pp. 4-10.

Wright, H.A., Bunting, S.C., Neuenschwander, L.F., 1976. Effect of fire on honey mesquite. Journal of Range Management 29, 467-471.

Wright, H.A., Klemmedson, J.O., 1965. Effect of fire on bunchgrasses of the sagebrushgrass region in southern Idaho. Ecology 46, 680-688.

Wrobleski, D.W., Kauffman, J.B., 2003. Initial effects of prescribed fire on morphology, abundance, and phenology of forbs in big sagebrush communities in Southeastern Oregon. Restoration Ecology 11, 82-90. 